\title{
Entrepreneurship Training Model with Quintuple Helix Approach Study on the Batik Creative Industry Craft Sector
}

\author{
Slamet Mudjijah ${ }^{1}$ \\ \{slamet.mudjijah@budiluhur.ac.id $\left.{ }^{1}\right\}$ \\ Faculty of Economy, Universitas Budi Luhur, Jl. Raya Ciledug, Jakarta, Indonesia ${ }^{1}$
}

\begin{abstract}
This research is motivated by research related to entrepreneurship development efforts. The government has provided various assistance programs to start-up entrepreneurs. However, the program has not been able to shape entrepreneurial behavior permanently. Researchers raise the issue of how the entrepreneurship training model that can leverage the performance of entrepreneurial craft. The research method used are descriptive explanatory, quantitative and qualitative approaches with research location in Purworejo District. The result of this research is the model of entrepreneurship training for batik creative business. The most dominant issues faced by batik entrepreneurs are excessive business expansion, environmental management, poor initial location selection, cash management. However, the problems that occur are not realized by batik entrepreneurs so that there is no hope to improve. Through this approach, business development activities for beginner entrepreneurs can be created an implementation model so that in a certain time interval can be evaluated business performance. The entrepreneurship training model for batik entrepreneurship is developed with quintuple helix approach including pre-training activities, batik training, advanced training, entrepreneurship training, mentoring, reporting and evaluation. The elements involved in the training are local government, batik entrepreneurs, academics, social community and environmental experts.
\end{abstract}

Keywords: Entrepreneurship, Entrepreneurship training model, Quintuple helix.

\section{Introduction}

Indonesia's economy will have strong fundamentals, if the people's economy has become the main actors of productive and competitive in the national economy. The greater the proportion of the population of a country who work as Entrepreneur, the more advanced the country. The lack of the number of entrepreneurs in Indonesia in the appeal of the total population, fueled by low interest or spirit of entrepreneurship in the country. Mental problems, lack of knowledge, the business climate is not in favor of the birth of Entrepreneurial beginner / new and certainly the most classic is the availability of adequate capital resources. Therefore, the development of entrepreneurship throughout society, particularly among young entrepreneurs should be a priority in national economic development.

Development of entrepreneurship for young people is expected to be a solution to improve the economic stability, the development of entrepreneurial potential possessed, so that in turn able to address labor issues, while encouraging the growth of the national economy [1]. The Government through the National Entrepreneurship Movement has made various efforts to develop entrepreneurship is good for prospective entrepreneurs, entrepreneurs beginners / new and entrepreneurs have long to pursue his efforts [2],[3].This assistance needs to be studied further to determine the accuracy of the target beneficiaries and to assess the policy of assistance to be able to enhance the economic empowerment of democracy in the present or in the future. Fostering entrepreneurship for entrepreneurs beginners should with a multidimensional approach that required the development of coaching model that is able to leverage business performance. This study aims to map the characteristics of beginner entrepreneurial ventures as recipients of government assistance, the problems faced and the progress of their business performance. Furthermore, based on a map of the novice entrepreneur condition coaching model developed entrepreneurship based on multidimensional lifting the root problems as a major issue. This model is expected to form a wellestablished entrepreneurs who will be able to better create a new field, thereby reducing unemployment.

\subsection{Entrepreneurial and Issues}

Entrepreneurship is a dynamic process of economic activities are planned taking into account thestrengths and weaknesses and the opportunities and obstacles in conducting a business that benefitted for welfare. Therefore important meaning contained in entrepreneurship, according [1], namely: science, art, behavior, nature, characteristics, and the character of the individual who has the ability to realize innovative ideas into real world creatively (create a new and different), So there are three main indicators of entrepreneurship, namely: to think something new (creative), act to do something new (innovative), and the desire to create value added (value added). 
Therefore, a person called the "entrepreneur" absolutely must have the ability to always think something new, do something new act, and the desire to create added value. Entrepreneurial success can be seen from the survival of businesses, providing jobs for the local population, increasing prosperity, improve the quality of life of users of the product, improving the environmental quality of the location of his business.

A common problem faced by new entrepreneurs to achieve success is the weakness of managerial like the founder of a business manager, financial reports traditionally do not have a registration, a computerized system that is weak, unclear which hamper management such as cash management that bad so do not have the funds for promotional activities and market research, lack of specialized professional staff, managers are generalists, not specialists [4]. Problems also often happens in the case of an unqualified anticipate the factors of uncertainty in the business at a later date, the initial poor site selection, initiating the expansion before it is ready, limited access to banking and financial markets, the lack of mastery of technology and information [5].

It can be concluded bring problems of entrepreneurs beginners in running business include weakness managerial, financial statements Traditionally, cash management, lack of promotion and market research, lack of specialized staff professionals, managers are generalists not specialists, unqualified anticipation of uncertainty factors in business in the future, a bad start site selection, initiating the expansion before it is ready, limited access to banking and financial markets, the lack of mastery of technology and information.

\subsection{Entrepreneurial Development of Entrepreneurship for Begiiners}

Fostering entrepreneurship in Indonesia at this time are derived from the government's budget is very diverse, from the training program as well as thecapital program [6] revealed that the research data shows a very diverse training program makes it possible for someone to follow more than one training activities in one fiscal year. Entrepreneurship education programs cannot be run in accordance with expectations, due to irregularities in the management of the program, the target group and mismatch irregularities training process. Most of the trainees returned to the original activity after attending a training program in the absence of improvement in economic activity. Life Skills Program activities are given post-training skills find various constraints such as poor management of financial management so that capital depleted aid used as initial assistance. This study develops entrepreneurial coaching model that includes pre-training activities, training, practice in the company, the funding process, business assistance, reporting and evaluation processes by participants.

Mulyani (2010) revealed that the novice entrepreneur development strategy must be addressed in order to realize: foster a conducive business climate; improving access to financial resources; improving market access through improved quality, design, and competitive prices; increase entrepreneurship and the ability of SMEs, especially in terms of entrepreneurial spirit; empowerment of Micro, which is the largest part of the national business actors is essential prioritized in order to encourage economic activities in the informal sector micro scale, especially who are still poor families through capacity building effort, skill, protection, and business coaching. Briefly, entrepreneurial coaching program for entrepreneurs beginners include education and training programs, mentoring (consultancy and monitoring), financing facilitation, IPR facilitation, facilitation of sale (domestic and foreign) [7].

Direction of government policy in the entrepreneurship development program in Indonesia at this time, namely the development effort aimed at the development of creative economic subsectors using the theory quadro-helix or quad-helix (Mulyani, et al, 2010). Triple-helix model of previously applied outlines synergies and partnerships in the development of creative economy took place betweenthe three main actors, i.e. government, private and intellectual [8].

While the quad-helix model of synergy and partnership lays in the development of creative economy took place between the four main actors, ie government, private, intellectual, and communities.

The concept of a quintuple helix which is quadruple helix concept development by integrating insights into the natural environment to attract businesses to the development of entrepreneurship coaching model. Although not many experts who express this concept, but the business development both now and in the future will be better if the concept of synergy quintuple helix model of entrepreneurship development, especially for novice entrepreneurs. Limited natural resources which allegedly as the difficulty factor for developing entrepreneurship needs to be maintained its nature by performing a reciprocal positive relationship between business and the natural environment [9].

\subsection{Conceptual Framework}

This study adopts the concept quadruple helix in building an entrepreneurial coaching model design for beginner entrepreneurs quintuple helix concept refers to the roles of academics, businessmen / entrepreneurs, government, socialand naturalenvironment in a creative economy based business management. Thus guidance to novice entrepreneurs a shared responsibility of academia, government, business and social community and natural environment feedback support. Coaching is multidimensional, involving various parties need a good 
communication system. Fostering entrepreneurship should be based on the root causes of what would be the characteristics of entrepreneur's beginners business. With the right coaching will improve business performance that would eventually form an established entrepreneur. The formation of an established entrepreneur will open wider employment opportunities and improve the community economy. The framework can be described as follows:

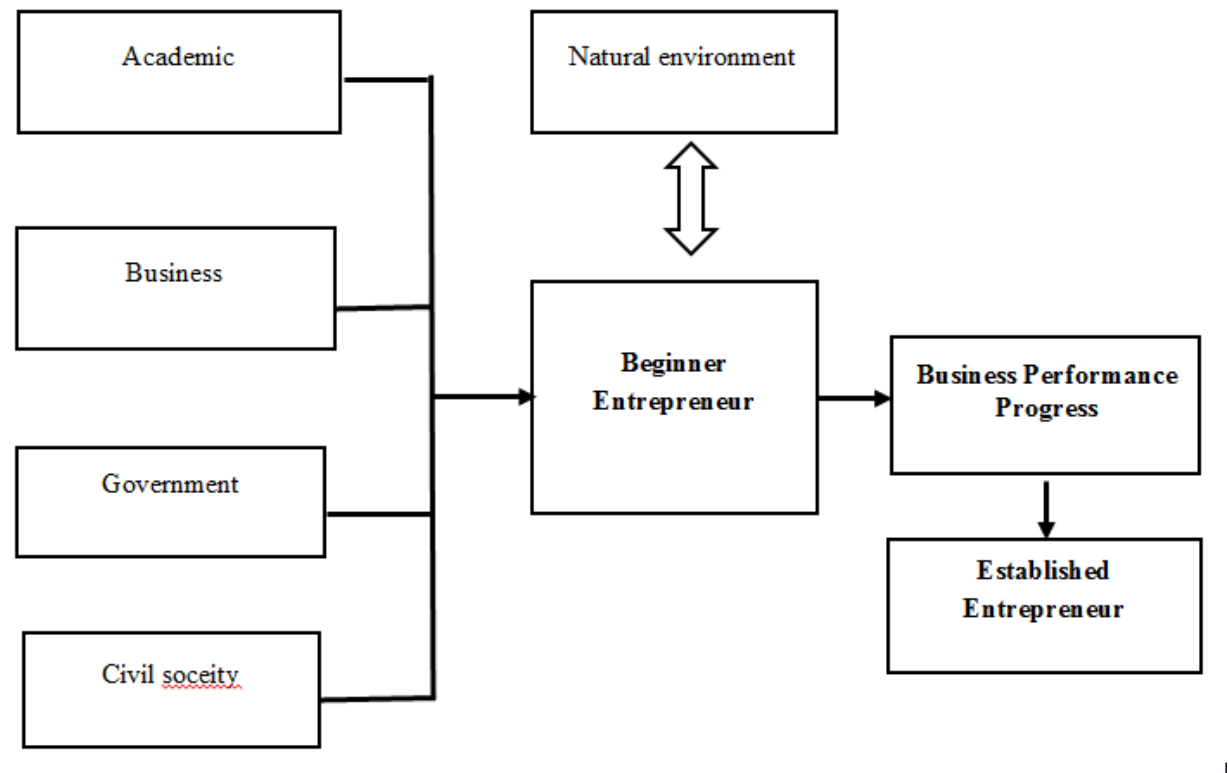

Fig. 1. Conceptual framework entrepreneurial coaching model.

\section{Research Method}

This study uses a variety of research approaches and descriptive exploratory survey. In this study, its scope should be limited only to the following matters: Location of the study consisted of three villages include Kedungkamal village, the village Grabag and the village. Limitations of the study included an entrepreneurial profile, challenges and opportunities for beginner's batik entrepreneurs, the need for coaching and development of entrepreneurship coaching model.

The research data conducted by using qualitative approaches. A qualitative approach to analyze data from appraisal expert (academic elements / academic, environmental experts, government / government) and practitioners (element entrepreneur / business) to be used in preparing model of entrepreneurship development and improvement of entrepreneurship coaching model.

\section{Result And Discussion}

The result of this research is the model of entrepreneurship training for batik creative business. The most dominant issues faced by batik entrepreneurs are excessive business expansion, environmental management, poor initial location selection, cash management. However, the problems that occur are not realized by batik entrepreneurs so that there is no hope to improve. The above obstacles in the view of researchers can be anticipated by the pattern of relationships between government, private, community, media and the environment as in the concept of quintuple helix. Through this approach, business development activities for beginner entrepreneurs can be created an implementation model so that in a certain time interval can be evaluated business performance.

The entrepreneurship training model for batik entrepreneurship is developed with quintuple helix approach including pre-training activities, batik training, advanced training, entrepreneurship training, mentoring, reporting and evaluation. The elements involved in the training are local government, batik entrepreneurs, academics, social community and environmental experts. Theentrepreneurship training model for batik entrepreneurship can be described as follows: 


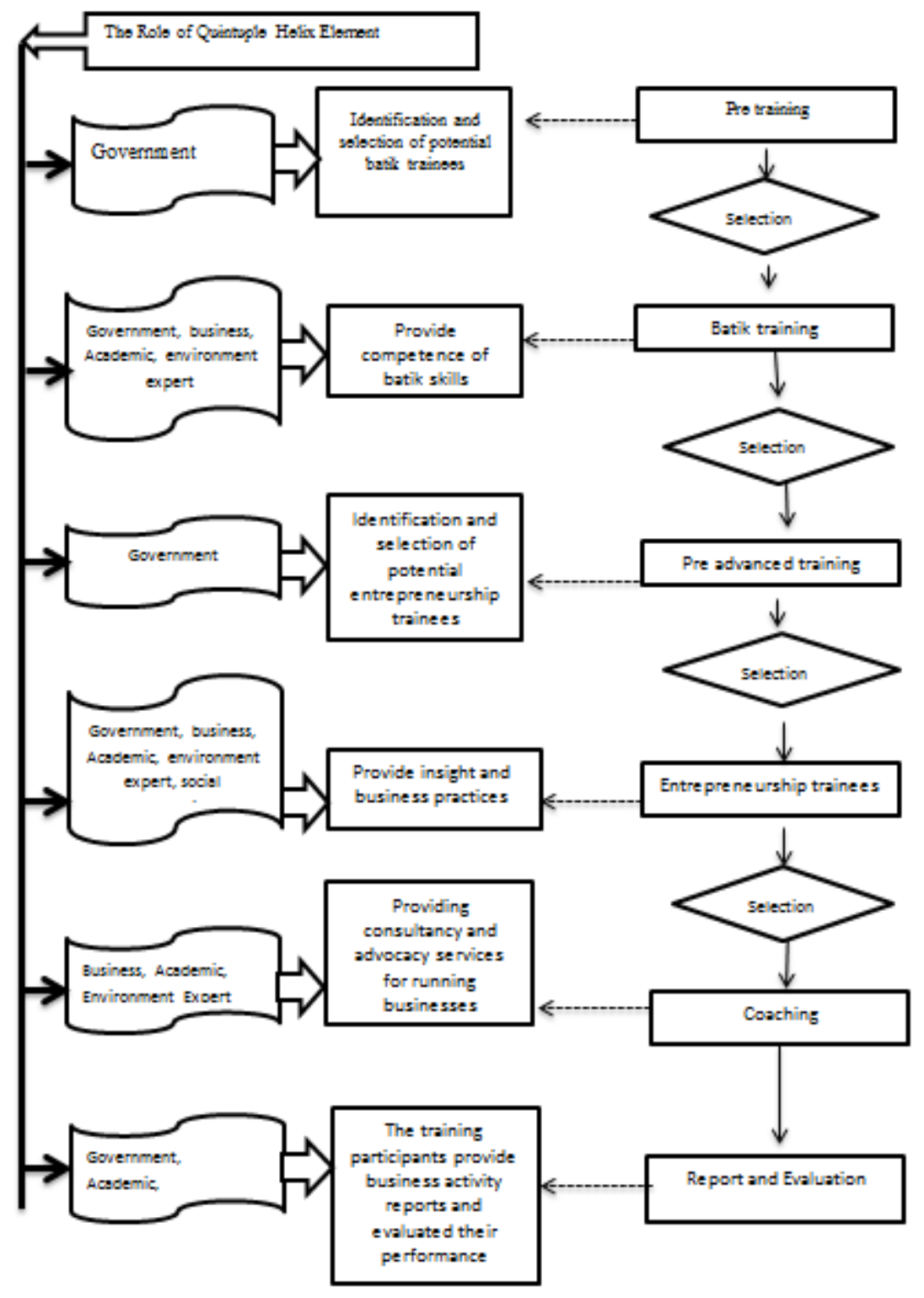

Fig. 2. The entrepreneurship training model for batik entrepreneurship. 
The model of entrepreneurship training to be used young people as an effective entrepreneur beginners can improve their business performance. The entrepreneurial coaching model with a multidimensional approach will maximize stakeholder participation that can be implemented by the government in increasing the number and performance of entrepreneurs. Coaching models produced can be used as the basis for further study and provide a basis for policy making to develop entrepreneurs.

\section{Conclusion}

Researchers raise the issue of how the entrepreneurship training model that can leverage the performance of entrepreneurial craft. The result of this research is the model of entrepreneurship training for batik creative business. The most dominant issues faced by batik entrepreneurs are excessive business expansion, environmental management, poor initial location selection, cash management. Through this research, business development activities for beginner entrepreneurs can be created an implementation model so that in a certain time interval can be evaluated business performance. The entrepreneurship training model for batik entrepreneurship is developed with quintuple helix approach including pre-training activities, batik training, advanced training, entrepreneurship training, mentoring, reporting and evaluation. The elements involved in the training are local government, batik entrepreneurs, academics, social community and environmental experts.

\section{References}

[1]E. M. Sangaji, "The Development of Entrepreneurship Training Model, Mentoring and Bookkeeping Fostering for Furniture Craftsmen in East Java, Indonesia.," Int. J. Learn. Dev., vol. 5, no. 3, 2015.

[2]S. Mudjijah, "Kreatifitas Bisnis dalam Home Industri Minyak Kelapa Meningkatkan Kesejahteraan Masyarakat Kecamatan Grabag, Kabupaten purworejo," Pros. Semin. Nas. Multidisiplin Ilmu. Univ. Budi Luhur, 2011.

[3]Z. K. Mudjijah, "Keberlanjutan Usaha Wirausaha Pemula Penerima Bantuan Pemerintah di Tangerang," Pros. Semin. Nas. Multidisiplin Ilmu. Univ. Budi Luhur, 2016.

[4]J. G. L. C. W. M. J. W. Petty, Kewirausahaan Manajemen Usaha Kecil. Jakarta: Salemba Empat, 2001

[5]A. Oni, E.O. and Daniya, "Development of small and medium scale enterprises: The role of government and other financial institutions," Arab. J. Bus. Manag. Rev., vol. 1, no. 7, 2012.

[6] dan A. B. P. Indriyatni, Lies. Panca Wahyuningsih, "Pengembangan Model Pelatihan Kewirausahaan untuk Perempuan Pengangguran di Kabupaten Dema,” J. Apl. Manaj., vol. 13, no. 2, 2015.

[7]D. Mulyani, Endang, "Penguatan Metodologi Pembelajaran Berdasarkan Nilai-Nilai Budaya Untuk Membentuk Daya Saing Dan Karakter Bangsa,” Kementeri. Pendidik. Nas., 2010 .

[8]H. Etzkowitz, "Incubation of incubators: innovation as a triple helix of universityindustry-government networks," Sci. Public Policy, vol. 29, no. 2, pp. 115-128, 2002.

[9]D. F. J. C. Carayannis, Evias G. Thorne and D. Barth, "The Quintuple Helix Innovation 
Model Global Warming as Challenge and Diverter Innovation.," J. Innov. Entrep., 2012. 